\title{
Corporate Governance and Company Characteristics on the Quantity of Environmental Disclosure
}

\author{
Indah Fajarini Sri Wahyuningrum ${ }^{1 *}$, Shanty Oktavilia $^{2}$, Andryan Setyadharma ${ }^{2}$, Dhini \\ Suryandari ${ }^{1}$, Pracita Netta $^{1}$, Arief Rahman ${ }^{3}$ \\ ${ }^{1}$ Department of Accounting, Faculty of Economics, Negeri Semarang University \\ ${ }^{2}$ Department of Economics Development, Faulty of Economics, Negeri Semarang University \\ ${ }^{3}$ Department of Accounting, Faculty of Business and Economics, Islam Indonesia University, Yogyakarta
}

\begin{abstract}
This study aims to examine the effect of Corporate Governance and Company Characteristics on the quantity of Environmental Disclosure. The population of this study is mining companies listed on the Indonesia Stock Exchange (BEI) for the period 2016-2018. Research samples of 32 companies with 96 units of analysis were taken based on purposive sampling. This study used multiple linear regression analysis technique with the IBM SPSS 21 program. The results of the regression analysis show that the proportion of independent commissioners, educational background of president commissioner, firm age, and firm size have effect on the quantity of environmental disclosure. Meanwhile, board size is proven not to have a significant effect on the quantity of environmental disclosure.
\end{abstract}

\section{Introduction}

In the past two decades, public awareness of the role of companies in society has increased significantly[1]. Many companies have contributed to the development of the economic and technological advances world but have been criticized for causing environmental problems. Globally, environmental issues have been the topic of this decade among various companies, governments, and public attention. Various cases of environmental problems have been rife both nationally and internationally. The presence of these cases is due to the existence of production process that has a negative impact on the environment caused by companies that have failed to manage and anticipate the adverse effects caused and endanger the community and ecosystem sustainability.

The process of corporate activities that because environmental problems has occurred many in Indonesia. The Office of the Environment (DLH) said that at least 10 factories were indicated to produce and dispose wastewater and did not have a Wastewater Discharge Permit (WWDP) from the 24 factories involved [2]. The Ministry of Environment and Forestry (KLHK) reported that during 2017-2018 there were still dozens of oil and gas as well as mining companies that polluted the environment. The Indonesian Forum for the

\footnotetext{
*Corresponding author: i.fajarini@mail.unnes.ac.id
} 
Environment (WALHI) said that there were 10 coal-fired steam power plants that contributed actively to air pollution in Jakarta by $20-30 \%$ [3].

Environmental problems that have occurred themselves are of particular concern to investors because they will show interest in companies that have implemented good environmental management. Good environmental management can be demonstrated by company's concern and responsibility through providing and disclose an information about environmental. Environmental Disclosure is defined as reporting by the company regarding the environmental impact of the activities and the effectiveness of company's programs as a way for the company to fulfil its environmental responsibilities and management of environmental resources [4].

There have been many studies observe the influence of corporate governance and company characteristics with environmental disclosure. Nevertheless, there are still inconsistencies in the results of testing. Therefore, this study aims to investigate whether any relationship between corporate governance (the proportion of independent commissioners, board size, educational background of a commissioner), company's characteristics (firm age and firm size) with environmental disclosure.

\subsection{Theoretical Framework}

Definition of Stakeholder theory related to environmental disclosure is the presence of a company determined by parties who have an interest, where the stronger the role of stakeholders in corporate operational activities, the greater the environmental disclosure that must be informed [5]. [6] argued that in legitimacy theory, environmental disclosure is a part of social and political pressures faced by a company regarding its environmental performance. This pressure makes the company will try to reveal more information related to environment. When the social system has been built between the community and the company, it will create legitimacy.

\subsection{Hypotheses}

\subsubsection{Proportion of independent commissioners}

Independent commissioners in a company can be defined as a board of commissioners in a corporate governance structure that is not from an affiliated party. Stakeholder theory emphasizes the importance of having a board of independent commissioners in the composition of the board aimed at protecting the interests of investors [7]. The existence of independent commissioners will cause monitoring carried out by board of commissioners will be more stringent, so that it can complicate the coordination process and cause an imbalance between the proportion of the board of independent commissioners on environmental disclosure. This can be seen from the results of research conducted by $[8,7]$ which find a positive influence between board of independent commissioners and environmental disclosure. On the other hand, [9] indicated that there was no relationship between the proportion of independent commissioners and environmental disclosure.

\section{$\mathrm{H}_{1}$ : Proportion of independent commissioners has a significant negative influence on the environmental disclosure}

\subsubsection{Board Size}

The quantity of environmental disclosure will get better along with the total members of the 
board of commissioners. This aims to facilitate controlling of manager's performance for the creation of effectiveness in the company. Stakeholder theory states that a company does not only operate in the interests of the company but the company must provide benefits to its stakeholders. In addition, the board of commissioners will conduct monitoring and direct the directors to make the company benefit its stakeholders. Legitimacy theory is used to explain the relationship of the board of commissioners that can encourage management to disclose environmental information that can improve economic prosperity for the community. Research conducted by $[10,9,8]$ found that size of board commissioners affect the level of environmental disclosure.

\section{$H_{2}$ : Board Size has a significant positive influence on the environmental disclosure}

\subsubsection{Educational Background}

Educational background of a commissioner is proven to have no relationship on the environmental disclosure. The presence of a president commissioner who is educated in economics and business tends to prioritize obtaining high profits rather than disclosing environmental information because of the large costs to be incurred. Research related to the effect of the educational background of the president commissioner with environmental disclosure has been investigated by Said et al. [11] but there are still result that show no effect.

\section{$\mathrm{H}_{3}$ : Educational background of President Commissioner has a significant negative influence on the environmental disclosure}

\subsubsection{Firm age}

Longer-established companies will generally become larger companies so that they are more willing to provide environmental disclosure information and more likely to adopt new policies to maintain their business [12]. Stakeholder theory explains that company activities will be seen by each stakeholder. Stakeholders will encourage the company to be broader in implementing and providing their environmental disclosure. Therefore, providing the extensive of environmental disclosures related to stakeholders expectations and beliefs may also increase the legitimacy of company activities carried out from the community. Firm age is proven affected to the quantity of environmental disclosure. This is indicated by research conducted by $[13,14]$. Research result of [12] at the companies that listed on the Ghana Stock Exchange (GSE) also confirms that firm age is significantly related to the quantity of environmental disclosure.

\section{$\mathrm{H}_{4}$ : Firm age has a significant positive influence on the environmental disclosure}

\subsubsection{Firm Size}

Legitimacy theory shows that large companies must act more in response to disclosure to have a greater influence on social expectations. It is because large companies have more stakeholders than small companies [15]. Therefore, larger companies will provide more environmental disclosure to show that the operational activities carried out are consistent and legitimate with good governance. Some prior studies indicated that size of company related to the quantity of environmental disclosure, among others $[13,14,16,17]$. Meanwhile, [18] prove that firm size does not have any relationship with the quantity corporate environmental disclosure.

\section{H5: Firm size has a significant positive influence on the environmental disclosure}




\section{RESEARCH METHODS}

This study use mining companies that listed on the Indonesia Stock Exchange (IDX) for the period year of 2016-2018 as a population. Research samples of 32 companies with 96 units of analysis were taken based on purposive sampling. Table 1 displays the sample selection criteria in this study.

Table 1. Sampling Procedure

\begin{tabular}{|l|l|}
\hline \multicolumn{1}{|c|}{ Criteria } & Total \\
\hline Research population & 47 \\
\hline $\begin{array}{l}\text { Mining companies that were not listed on the IDX in a row for } \\
\text { the period of 2016-2018. }\end{array}$ & $(6)$ \\
\hline $\begin{array}{l}\text { Mining companies that did not publish annual report and or } \\
\text { sustainability report during 2016-2018. }\end{array}$ & $(9)$ \\
\hline Total Samples & 32 \\
\hline Total units of analysis (2016-2018) & 96 \\
\hline
\end{tabular}

This study using the quantity of environmental disclosure as the dependent variable and five independent variables, namely the proportion of independent commissioners, size of the board of commissioners, the educational background of principal commissioner, firm age, and firm size. Environmental disclosure as an independent variable was measured by content analysis [19]. Content analysis was done by calculating the sentence quantity of each of the 30 specific items of GRI Standards 2016 by referring to the research conducted by [20]. Score 0 if there was no one disclosure sentence, score 1 if there were one to two sentences, score 2 if there was one paragraph (minimum of three sentences), score 3 if there were sentences of half an A4 page, score 4 if there was one A4 page, and score 5 if more than one A4 page. Table 2 shows the explanation and measurement of each variable.

Table 2. Variable measurement

\begin{tabular}{|c|c|c|c|}
\hline No & Variables & Definition & Measurement \\
\hline 1 & $\begin{array}{l}\text { Environment } \\
\text { al Disclosure } \\
\text { (ED) }\end{array}$ & $\begin{array}{l}\text { Disclosure of environmental } \\
\text { information by a company. }\end{array}$ & Content analysis \\
\hline 2 & $\begin{array}{l}\text { Proportion of } \\
\text { Independent } \\
\text { Commission } \\
\text { ers (IND) }\end{array}$ & $\begin{array}{l}\text { Total independent } \\
\text { commissioners from outside } \\
\text { company with having no } \\
\text { relationship with the } \\
\text { company. }\end{array}$ & $\frac{\text { Total independent commissioners }}{\text { Total members of board of commissioners }} \times 100 \%$ \\
\hline 3 & $\begin{array}{l}\text { Size of } \\
\text { Board of } \\
\text { Commission } \\
\text { ers } \\
\text { (BOARD) }\end{array}$ & $\begin{array}{l}\text { The number of board of } \\
\text { commissioners in a } \\
\text { company consists of } \\
\text { president commissioner, } \\
\text { independent commissioner, } \\
\text { and commissioner. }\end{array}$ & $\begin{array}{l}\text { Total member of board of commissioners in } \\
\text { a company }\end{array}$ \\
\hline
\end{tabular}




\begin{tabular}{|l|l|l|l|}
\hline $\mathbf{4}$ & $\begin{array}{l}\text { Educational } \\
\text { Background } \\
\text { of President } \\
\begin{array}{l}\text { Commission } \\
\text { er (EDUBG) }\end{array}\end{array}$ & $\begin{array}{l}\text { Educational background of a } \\
\text { president commissioner in } \\
\text { the fields of economics and } \\
\text { business which will be } \\
\text { directly in contact with the } \\
\text { company. }\end{array}$ & $\begin{array}{l}\text { Score 1: Economic and business education } \\
\text { Score 0: Education other than economics } \\
\text { and business }\end{array}$ \\
\hline $\mathbf{5}$ & $\begin{array}{l}\text { Firm Age } \\
\text { (AGE) }\end{array}$ & $\begin{array}{l}\text { Firm age that indicates the } \\
\text { length of a company from } \\
\text { listing to the year of } \\
\text { research }\end{array}$ & Ln (Total Month) \\
\hline $\mathbf{6}$ & $\begin{array}{l}\text { Firm Size } \\
\text { (SIZE) }\end{array}$ & $\begin{array}{l}\text { Large or small size of a } \\
\text { company }\end{array}$ & Ln (Total asset) \\
\hline
\end{tabular}

This study used multiple regression technique, therefore, equation 1 shows the multiple regression equation.

$$
\mathrm{EDQ}=\alpha+\beta 1 \mathrm{IND}+\beta 2 \mathrm{BOARD}+\beta 3 \mathrm{EDUBG}+\beta 4 \mathrm{AGE}+\beta 5 \mathrm{SIZE}+\mathrm{e}
$$

\section{Results and Discussions}

The classic assumption test in this study use Kolmogorov-Smirnov with the significance value of 0.091 . It point out that the residual data is normally distributed. The multicollinearity test shows that all variables have a tolerance value $>0.10$ and VIF $<10$. This indicates that there is no multicollinearity between variables in the regression model of this study. Another classic assumption test of heteroscedasticity is done by Glejser. The significance values of all variables are more than sig $>0.05$, therefore, there is no heteroscedasticity. Furthermore, the autocorrelation test of this study uses a run test with a test value of -2.67494 and a probability of 0.151 with a significance of 0.05 . As a result, in this regression model there was no found autocorrelation.

Based on the ANOVA test result, the regression model in this study can be used to predict ED because the $F$ count value is 12.081 with a probability of 0.000 less than 0.05 . The coefficient of determination shows the Adjusted $\mathrm{R}^{2}$ value of 0.368 . It means that $36.8 \%$ of EDQ variations can be explained by independent variables and the remaining $63.2 \%$ is described by other factors. Equation 2 shows the regression equation based on multiple linear regression of this study.

$\mathrm{ED}=-100.447-31.524 \mathrm{IND}+1.367 \mathrm{BOARD}-6.038 \mathrm{EDUBG}+6.476 \mathrm{AGE}+3.319 \mathrm{SIZE}+\mathrm{e}$ Table 3 displays the results of research hypothesis testing.

Table 3. Hypothesis Testing Results

\begin{tabular}{lllll}
\hline Hypothesis & Measurement & $\boldsymbol{\beta}$ & Sig. & Results \\
\hline $\mathrm{H}_{1}$ & $\begin{array}{l}\text { Proportion of independent } \\
\text { commissioners has a significant negative } \\
\text { influence on the environmental } \\
\text { disclosure }\end{array}$ & -100.447 & 0.009 & Accepted \\
\hline $\mathrm{H}_{2}$ & $\begin{array}{l}\text { Board Size has a significant positive } \\
\text { influence on the environmental disclosure }\end{array}$ & -31.524 & 0.085 & Rejected \\
\hline $\mathrm{H}_{3}$ & $\begin{array}{l}\text { Educational background of President } \\
\text { Commissioner has a significant negative } \\
\text { influence on the environmental disclosure }\end{array}$ & -6.038 & 0.017 & Accepted \\
\hline
\end{tabular}




\begin{tabular}{lllll}
\hline $\mathrm{H}_{4}$ & $\begin{array}{l}\text { Firm age has a significant positive } \\
\text { influence on the environmental disclosure }\end{array}$ & 6.476 & 0.001 & Accepted \\
\hline $\mathrm{H}_{5}$ & $\begin{array}{l}\text { Firm size has a significant positive } \\
\text { influence on the environmental disclosure }\end{array}$ & 3.319 & 0.000 & Accepted \\
\hline
\end{tabular}

\subsection{The Effect of the Proportion of Independent Commissioners on the Environmental Disclosure}

This study's result point out that the proportion of independent commissioners has significantly effect on the environmental disclosure. Meanwhile, the relationship was negative. Thus, it can be concluded that the larger number of independent commissioners in the company, the environmental disclosure efforts undertaken by the company will be lower. In addition, the increasing number of independent commissioners in the company will make the coordination process more difficult and ineffective in providing control to increase environmental disclosure by the company. So, the environmental disclosure will decrease along with the lack of control. The negative effect of the proportion of independent commissioners on environmental disclosure can also be affected by the lack of active presence of the board of independent commissioners in corporate supervision activities. The results of this study is consistent with prior research conducted by [13].

\subsection{The Effect of Board Size on the Environmental Disclosure}

According to the significance value from table 3, the second hypothesis is not proven or rejected. This indicate that the size of board commissioners in the companies tends not to have an interest in the quantity of environmental disclosure. Total number of board commissioners owned by a company indicate that none of the board of commissioners is concerned with environmental management [6]. The board of commissioners may not have any relationship with the environmental disclosure because the duties and responsibilities of the board commissioners are as follows; give advice to the board of directors, monitor company policies and management, be responsible for company losses and company bankruptcy due to lack of supervision or advice. Thus, the board of commissioners is more focused on the financial aspects. Result of this study is in line with prior research conducted by [13].

\subsection{The Effect of the Educational Background of President Commissioner on the Environmental Disclosure}

Therefore, the third hypothesis is proven or accepted. This means that companies that have a president commissioner with an economic and business educational background will have lower scores of environmental disclosure equated to companies that do not have a president commissioner with an economic and business educational background. High educational background of the president commissioner is likely to make decisions to increase profit as high as possible compared to environmental disclosure. ]13] reveal that a president commissioner with a background in legal education has effect on the environmental disclosure. This is due to the president commissioner will understand and know the laws and regulations to manage the company or the principles behind the level of voluntary disclosure, especially environmental disclosure.

\subsection{The Effect of Firm Age on the Environmental Disclosure}

The research result shows that firm age significantly related to the quantity of environmental 
disclosure. Based on these results, the fourth hypothesis is proven or accepted. Longestablished companies will have more experience so that they will have more understanding of environmental disclosure so that they are able to provide disclosure information needed for its stakeholders better. Companies with longer lifespan also have reporting capabilities that increase from time to time. Companies that have a longlife with a longer social existence have relatively higher legitimacy and higher involvement of social and environmental responsibility than younger companies. This finding is in line with research conducted by $[12,13,14]$.

\subsection{The Effect of Firm Size on the Environmental Disclosure}

The research result shows that firm size significantly effect on the environmental disclosure. According to the result on table 3, the fifth hypothesis is proven or accepted. According to [21], companies with larger size will pay more attention to environmental issues so that they will be better at disclosing environmental disclosure. When the companies grow, they are more exposed because their image and size by the community will get more demands and pressure from the community. This causes the companies to become more responsible for environmental issues and to provide further information about the company's activities by disclosing environmental information. Large companies must act more in response to disclosure to have greater influence [15]. This research is in line with what was done by $[12,13,16]$.

\section{Conclusions}

This study investigates the effect of corporate governance (the proportion of independent commissioners, educational background of president commissioner, board size), company characteristics (firm age, and firm size) on the quantity of environmental disclosure mining companies in Indonesia. The outcomes of this study indicated that the proportion of independent commissioners, educational background of president commissioner, firm age, and firm size have an impact on environmental disclosure quantity. In contrast, this study failed to provide evidence that board size is a contributing factor of environmental disclosure. In addition, the results of this study can be used as a communicating procedures for decision making associated to environmental disclosure by regulators, companies, and investors. Meanwhile, there are some limitations in this study. Since many countries still do not require environmental disclosure to be reported in their financial statements, most of the mining companies do not provide sustainability report or any report that related to environmental disclosure. Second, this study only focus on mining companies that listed in Indonesia Stock Exchange (IDX) in 2016-2018. Automatically, this points considerably decrease the total number of companies as the sample size because there were less than 50 mining companies listed in that period. Forthcoming studies are likely to use other industries beside mining industry and put other variables that are assumed have an effect on environmental disclosure.

\section{References}

1. Andreas, Desmiyawatia, \& Liani, W, The Effect of Firm Size, Media Exposure and Industry Sensitivity to Corporate Social Responsibility Disclosure and Its Impact on Investor Reaction. International Conference on Accounting Studies (ICAS) (2015) 
2. Radar, 24 Pabrik Bermasalah, Terindikasi Cemari Sungai Cileungsi. https://www.radarbogor.id/2019/09/17/24-pabrik-bermasalah-terindikasi-cemarisungai-cileungsi/ (2019)

3. CNN, Walhi: 10 PLTU Batu Bara Sumbang 30 Persen Polusi Jakarta. https://www.cnnindonesia.com/nasional/20190716161616-20-412627/walhi-10- pltubatu-bara-sumbang-30-persen-polusi-jakarta (2019)

4. Ohidoa, T., Omokhudu, O. O., \& Oserogho, I. A. F, Determinants of Environmental Disclosure. International Journal of Advanced Academic Research, 2(8) (2016)

5. Elsayih J, Tang Q and Lan Y-C, Corporate governance and carbon transparency: Australian experience Accounting Research Journal 31, 405- 22 (2018)

6. L. Liao, L. Luo, Q. Tang, Gender diversity, board independence, environmental committee and greenhouse gas disclosure, The British Accounting Review 47, 409-24 (2015)

7. Odoemelam, N., \& Ofoegbu, G. N. (2018). Corporate Board Characteristics and Environmental Disclosure Quantity: A Comparative Analysis of Traditional and Integrated Reporting Evidence. Preprints. https://doi.org/10.20944/preprints201808.0419.v1

8. Rupley, K. H., Brown, D., \& Marshall, R. S, Governance, Media, and the Quality of Environmental Disclosure. Journal Accounting Public Policy, 31(6), 610-640 (2012)

9. Rabi, A. M, Board Characteristics and Environmental Disclosure: Evidence from Jordan. International Journal of Business and Management, 14(2) (2019)

10. Rao, K. K., Tilt, C. A., \& Lester, L. H, Corporate Governance and Environmental Reporting an Australian Study. Corporate Governance: The International Journal of Business in Society, 12(2), 143-163 (2012)

11. Said, R., Omar, N., \& Abdullah, W. N, Empirical Investigations on Boards, Business Characteristics, Human Capital and Environmental Reporting. Social Responsibility Journal, 9(4), 534-553 (2013)

12. Welbeck, E. E., Owusu, G. M. Y., Bekoe, R. A., \& Kusi, J. A, Determinants of Environmental Disclosures of Listed Firms in Ghana. International Journal of Corporate Social Responsibility (2017)

13. Chandok, R. I. S., \& Singh, S, Empirical Study on Determinants of Environmental Disclosure: Approach of Selected Conglomerates. Managerial Auditing Journal, 32(4), 332-355. https://doi.org/https://doi.org/10.1108/MAJ-03- 2016-1344 (2017)

14. Wahyuningrum, I. F. S., \& Budihardjo, M. A. (2018). Relationship between Company Financial Performance, Characteristic and Environmental Disclosure of ASX Listed Companies. The 3rd International Conference on Energy, Environmental and Information System (ICENIS 2018), 73. https://doi.org/https://doi.org/10.1051/e3sconf/20187310024 (2018)

15. Ohidoa, T., Omokhudu, O. O., \& Oserogho, I. A. F, Determinants of Environmental Disclosure. International Journal of Advanced Academic Research, 2(8) (2016)

16. Burgwal, D. van de, \& Vieira, R. J. O, Environmental Disclosure Determinants in Dutch Listed Companies. Revista Contabilidade and Financas Accounting and Finance Review, 25, 60-78 (2014)

17. Gatimbu, K. K., \& Wabwire, J. M, Effect of Corporate Environmental Disclosure on Financial Performance of Firms Listed at Nairobi Securities Exchange, Kenya International Journal of Sustainability Management and Information Technologies, 2(2), 1-6.https://doi.org/10.11648/j.ijsmit.20160201.11 (2016)

18. Elshabasy, Y. N, The Impact of Corporate Characteristics on Environmental 
Information Disclosure: An Empirical Study on The Listed Firms in Egypt. Journal of Business and Retail Management Research (JBRMR), 12(2) (2018)

19. Krippendorff, K, Content Analysis : An Introdusction of Its Methodology (II). Sage Publications, Inc (2004)

20. Raar, J, Environmental Initiatives: Towards Triple-Bottom Line Reporting. Corporate Communications: An International Journal, 7(3), 169-183 (2002)

21. Zhang, J., Guoa, H., Lia, B., \& Wang, W, The Influence of Financial Factors on Environmental Information Disclosure in China Chemical Industry. International Journal of Global Environmental (2008) 